\title{
Two Clinical Traits in Melancolic Depressions
}

\author{
Fernando Arce Hochkofler* \\ Psychoanalyst in La Paz, Bolivia \\ *Corresponding author: Fernando Arce Hochkofler, Psychoanalyst in La Paz, Bolivia
}

\begin{tabular}{|c|c|}
\hline ARTICLE INFO & ABSTRACT \\
\hline Received: 幽 July 13, 2019 & Citation: Fernando Arce Hochkofler. Two Clinical Traits in Melancolic Depressions. Biomed \\
\hline ublished: & ת \\
\hline
\end{tabular}

\section{Introduction}

In patients with melancholic depression two characteristic clinical features are observed: first, that of a certain lability to identify with the other in their interpersonal relationships; second, the tendency to let go, abandon their friendship and relationship.

From childhood to adulthood, we observe in these patients the tendency to interact in a mirror when they are talking with another person. This occurs in the vocal space (of the voice) and shows their lack of being well anchored in their identity and in their own structure; as if with each interlocutor that they considered superior, they could not avoid the immediate impulse to duplicate, sometimes their accent and their gestures; others, their fears and their desires.

The other feature is that of abandoning, letting go of their relationships as if they were unable to sustain and cope with the tensions generated by the processes of maturation and growth of the people who build a bond. Since childhood, the depressive person is inclined to establish relationships with a strong affective and / or adhesive attachment, causing rejection by those who are the object of attachment, under the motivation of feeling this approach as an eroticized, possessive or homosexual relationship or, at least, to that type of disqualifying judgments. In reality, the melancholic depressed child has a bad approach to his peers because he can't manage the social codes of psychic distance, of character to set limits and of fun with tolerance; therefore, he/she tends to isolate himself. Moreover, his complacent docility exposes him to being used, humiliated and even exploited; when not, manipulated, dazzled or subdued by someone who takes advantage of their need for affection and social recognition. As a result, a paranoid mechanism of mistrust is triggered unconsciously, which, in adult life, can acquire the dimensions of a self-destructive drive. Therefore, the tendency to abandon is a mixture of compulsion to repeat the traumatic suffered; from the anguish of abandonment (abandon before being abandoned) and; of the defense mechanism to avoid being annulled / alienated by the other.

When analyzing the origin of these traits in patients with melancholic depression, there are various forms of abandonment / rejection occurred in early childhood, because for various reasons the parents fail to provide adequate emotional support to the newborn. These range goes from rejection, physical or psychological abandonment, the early disappearance of one of the parents or both, to discrimination and lowering as a blamed object. This child, future depressive patient, experiences helplessness during this critical period of his development, when he becomes a subject, when he needs to be recognized as the object-cause of his parents' desire. It is precisely during the first months of life, when the ego forms when the newborn anticipates the fragmented perception of his body, identifying with the mirror image of his mother as a unifying whole. The presence of a third party (the father) consolidates this operation that occurs with the adult who offers the child greater objetal constancy (whether the mother or a substitute), by staying longer in a relationship of vital dependence. The image alienated to that maternal imago, of his auto erotized body by the vocal stimulation (the maternal voice), by the way he is holding and handling and by the contact with the body of the mother; it becomes the first representation of the ego. It is an ideal ego that constitutes the basis of the successive identifications of its psychic evolution; it is imbued with the ideals and desires of the mother and; it configures the nucleus that begins to repress that his mother rejects in the conscious and unconscious planes. We say that the mother constitutes the Other with respect to the child, as she acts as the field of the word and, in so far, as she imposes on him omnipotently language and desire. 
Lacan [1] calls this period the stage of the mirror because it forms the subject of the unconscious (Je) and inaugurates the dialectic of the identifications of the psychological self (Moi) and the stages of the libidinal development (oral, vocal, scopic, anal and phallic drives). Therefore, if the young child is not well received in the field of the Other (that of the word and desire), he is weak in all his structure, suffering from a lack of stowage or anchoring that undermines his basic identification; which makes him labile in his identifications and develops a feeling of himself as insufficient or inadequate that makes him distrustful and prone to self-absorption in his solitude. Any detriment suffered in this period, determines a drive return, with regression and fixation. Therefore, in the acute depressive states of adult patients, the return of the voice of the Other is observed as a paranoid object or, the fantasmatic appearance of a third party that threatens death or that comes to supplant the subject, in the manner of a double; with the consequent uncontrollable anguish.

When the child does not accede to recognition as a subject, he displays a first awareness: "Something is wrong with me not to be worthy of being loved". Then he develops a feeling of insufficiency or inadequacy and begins to overact to attract attention. We then witness the fact of becoming extremely sensitive to the unconscious desire of the Other until we acquire the necessary plasticity to offer the countenance required by the Other to give it recognition. He automatically asks himself: "What does the Other want?" The child immediately becomes an anonymous buffoon, indispensable solicitous, mute rebel, invisible scholar who does notcause problems, occupies any symbolic place that the Other demands, in the way of a joker. At the ame time, oral and anal sadism are exacerbated in him, in an effort to retain the maternal object devoured and being vomited, and the valuable anal object that he no longer wants to deliver. Upon the early feeling of inadequacy, he will be blamed for any mistake he makes and will hate himself as if he were always guilty, manifesting self-destructive impulses of unconscious anger and rebellion towards his parents. Subsequently, disqualification and self-denigration is assumed by the superego, which will spur him on and on. And each loss, each abandonment / rejection will plunge you into the black mud of anger and melancholy and as this becomes your comfort zone, learn to enjoy the sadness and loneliness.

If the affective abandonment occurs in a later period, in an equally critical stage such as puberty (10-14 years); the internalized aggression becomes a feeling of self-insufficiency that is counteracted by a neurotic mania due to doubt, indecision and the obsession of perfection; in a pathological inhibition of affectivity. In such cases, we prefer to resort to the old concept of characterogenic depression [1].

The two cynical features described above facilitate diagnosis and preventive intervention that deciphers the death drive that destroys patients with melancholic depression.

\section{Acknowledgement}

None.

\section{Conflict of Interest}

No conflict of interest.

\section{References}

1. Lacan J (1949) The mirror stage as a formator of the function of the Self (Je) as it is revealed to us in the psychoanalytic experience. In Writings, vol. I, Paris, Éditions du Seuil, 1966. Trad. by Tomás Segovia (Eds.), México, Siglo XXI editores s.a., $14^{\text {th }}$ (edn.). 1988, p. 86-93.

2. Bohm E (1953) Handbook of Psychodiagnosis of RORSCHACH, Hans Huber, Verlag, Bern, 1957, $2^{\text {nd }}$ (edn.). Trad. by A Serrate, Ediciones Morata SA (Eds.), Madrid 1977, 14 ${ }^{\text {th }}$ (edn.). pp. 319-334.

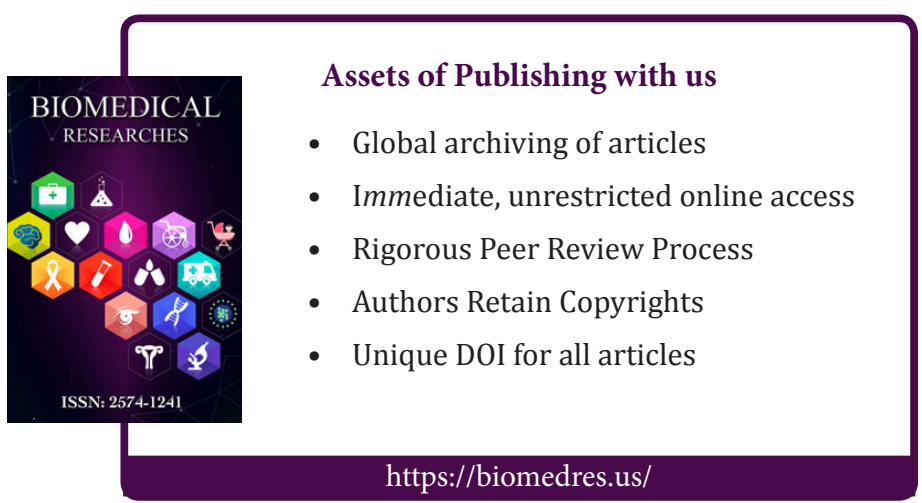

